\title{
Mulheres e carnavais no Rio de Janeiro: as representações da imprensa entre 1950 e 1962
}

\author{
Women and carnival frolics in Rio de Janeiro: their \\ representations in the press from 1950 to 1962.
}

Ellen Karin Dainese Maziero ${ }^{1}$

RESUMO

O presente artigo tem como objetivo discutir as representações construídas pela imprensa quanto à presença das mulheres de diferentes segmentos sociais nos carnavais da cidade do Rio de Janeiro, de 1950 a 1962. Entendido como um tipo de festejo libertador das convenções sociais, o carnaval possibilitava o extravasamento e transgressões de algumas mulheres, que aproveitavam o clima dos folguedos para manifestar comportamentos mais livres. Por meio da cobertura dos carnavais realizada pelas revistas O Cruzeiro e Manchete e pelos jornais Correio da Manhã e O Globo, foi possível apreender as percepções da imprensa sobre a participação feminina nessas celebrações.

Palavras chave: Brasil. Rio de Janeiro. Mulheres. Carnaval. Representações da Imprensa.

ABSTRACT

This paper was carried out to discuss representations produced by the press concerning the presence of women of different social levels in carnival frolics held in Rio de Janeiro from 1950 to 1962 . Viewed as a kind of merrymaking enjoying a sense of liberation from social conventions, carnival allows outpouring and transgression on the part of some women, who availed themselves of the merry-making opportunity to enjoy more liberating kinds of behavior. By covering the carnival celebrations carried out by magazines such as $\mathrm{O}$ Cruzeiro and Manchete and the newspapers Correio da Manhã and O Globo, one managed to capture the perceptions of the press on the participation of women in such celebrations.

Keyword: Brazil. Rio de Janeiro. Women. Carnival. Representations by the press.

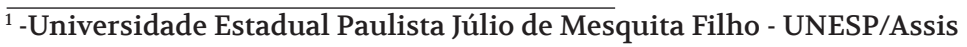




\section{Introdução}

Este texto discute as representações realizadas pela imprensa sobre as mulheres brincantes, de diferentes estratos sociais, nos carnavais do Rio de Janeiro durante o período de 1950 a 1962. É importante assinalar, que os anos definidos neste estudo, podem ser caracterizados como típicos de uma sociedade em transição no que tange a uma presença mais assertiva das mulheres na sociedade, haja vista que essas ocupavam apenas $14,7 \%$ da força de trabalho total no Brasil em 1950, percentual que passou para 17,9\% em 1960 (DIAS, 1993, p. 84). E, igualmente, evidenciou-se uma nova forma de fazer o carnaval no país, sinalizando mudanças significativas no modo das mulheres brincarem esses festejos e aparecerem nos registros da imprensa.

Os anos 1950, apesar de controversos, são descritos por parcela da historiografia como representativos do domínio das escolas de samba no cenário carnavalesco. A socióloga Maria Isaura Pereira de Queiroz (1992) assinala que essa mudança no perfil dos festejos significou uma vitória do carnaval popular no Brasil - tendo como suporte as escolas de samba - sobre o chamado grande carnaval. ${ }^{1}$ A historiadora Zélia Lopes da Silva, por sua vez, discorda de tal interpretação ao estudar o carnaval da cidade de São Paulo, advertindo para o fato de que a ditadura varguista e a Segunda Guerra Mundial provocaram desestruturações significativas nos festejos carnavalescos (SILVA, 2004b), reforçada pelo desinteresse do próprio folião pelas antigas modalidades de brincar os carnavais. ${ }^{2}$ Esses dados, para a autora, dificulta a concordância com a periodização proposta por Queiroz, a qual considera que de meados da década de 1940 em diante o carnaval torna-se popular, apoiado nas escolas de samba.

Independente de divergências de periodização, tal postura não ofusca o consenso entre os pesquisadores sobre o crescimento das escolas de samba no Rio de Janeiro, as quais passaram a ocupar cada vez mais o espaço do carnaval de rua, imprimindo outra forma de brincar os festejos momescos no país. Apesar da crescente posição que as escolas de samba vinham conquistando no carnaval de rua do Rio de Janeiro, não é possível restringir o centro dos folguedos carnavalescos a seus desfiles, haja vista a vitalidade apresentada pelos carnavais nos salões, que atraíam um grande número de foliões e foram elogiados pela imprensa por sua animação, indicando a descentralização desses festejos que sinalizava também para modificação dos costumes e da moral societária.

Se no decurso da década de 1950 ocorrem alterações nessas folganças carnavalescas, a década seguinte traz outras variações. Por isso, optou-se por definir o ano de 1962 como baliza final para a temática aqui proposta em razão das mudanças nas representações sobre as

\footnotetext{
${ }^{1}$ O chamado "Grande Carnaval" surgiu na metade do século XIX e era constituído pelas grandes sociedades carnavalescas que tinham como finalidade a organização de desfiles luxuosos de carros alegóricos para exibição na Terça-Feira Gorda. Desta nova forma de festejar o carnaval fazia parte também o "corso", que consistia em passeios, a princípio de carruagem e, posteriormente, de automóvel, em que as famílias desfilavam luxuosamente fantasiadas na tarde dos dias consagrados à folia (QUEIROZ, 1992).

${ }^{2}$ A autora afirma que a ditadura varguista e a guerra afetaram drasticamente a forma de brincar o carnaval, em decorrência de limitações e proibições que passaram a vigorar no período, como a censura, o forte esquema policial, o racionamento de combustível e a dificuldade em adquirir determinados produtos carnavalescos, entre outras (SILVA, 2004b).
} 
mulheres folionas nos carnavais fechados cobertos pela imprensa, que passaria a enxergar nos comportamentos de determinadas brincantes, mesmo que gradualmente, uma postura mais evidente de sua sensualidade.

É preciso salientar, entretanto, que regras morais estabelecidas em períodos anteriores coexistiam com os novos valores em construção. Nesse sentido, as representações da imprensa citada estiveram relacionadas significativamente ao uso do biquíni em diversos espaços dos folguedos. Em fins da década de 1950, embora o "biquíni" já fizesse sua aparição nos carnavais de salão, ainda não constituía a tônica das fantasias usadas nesse tipo de folguedo ${ }^{3}$. Além do mais, o biquíni do período confundia-se ao duas-peças, traje de banho que deixava a pele na altura do estômago exposta (CHATAIGNIER, 2010), permanecendo relativamente comportado. A revista $O$ Cruzeiro noticiaria a prática do uso do biquíni nas praias cariocas e paulistas somente no verão de 1960/1961(BIQUÍNI...,1961, p. 80), embora seja possível observar que a sua difusão se deu de forma rápida a ponto de já constar nas proibições da polícia para o carnaval de 1961(FANTASIA..., 1961,p. 09). Aos poucos, os biquínis passariam a servir de base para elaboração das fantasias usadas pelas folionas da zona sul da cidade nos bailes fechados, permitindo um desvelar do corpo que seria amplamente explorado pela imprensa. A "novidade", entretanto, indica mudanças na forma dessas mulheres se apresentarem nos carnavais.

Transformações de diferentes dimensões também atingiram as escolas de samba. A partir de 1962, por exemplo, tem-se a montagem de arquibancadas na Avenida Rio Branco e a venda de ingressos ao público ${ }^{4}$, que inicializaria um processo irreversível de comercialização dos desfiles (CAVALCANTI, 1994, p.26) das escolas de samba. Verifica-se na década de 1960, também, a ampliação da participação da classe média nos seus desfiles. Essas alterações, por sua vez, revestiriam os festejos de uma maior sensualidade, que se torna visível na década de 1970, o que não será tratado neste texto por fugir da periodização proposta.

À medida que mudanças nos costumes ocorreram de forma mais intensa, o carnaval se modificou, assim como as representações da imprensa que deixaram o aspecto sensual mais explícito nas seleções e coberturas realizadas por seus periódicos quanto à postura assumida pelas mulheres nessas celebrações. Sendo assim, o interesse deste artigo não é outro senão apreender as representações sobre as mulheres, de diferentes estratos sociais, nos festejos carnavalescos, presentes nos periódicos selecionados para pesquisa - O Cruzeiro, Manchete, Correio da Manhãe $O$ Globo, fontes que se mostraram importantes devidoà sua representatividade entre os veículos da indústria cultural.

Faz-se necessário, no entanto, questionamentos sobre os interesses que envolviam a produção das matérias de carnaval, os meios de sua realização, os conteúdos e imagens que eram selecionados, o espaço que a temática carnavalesca ocupava nas páginas dessas

${ }^{3}$ O biquíni foi uma invenção do estilista francês Louis Réard, ainda em 1946, mas sua difusão e aceitação ocorreram, de fato, somente a partir dos anos 1960 (BRAGA, 2004).

${ }^{4}$ Se a comercialização do carnaval começou de modo mais contundente ainda em 1962, foi em 1976 que adquiriu um caráter espetacular, com o crescimento de agremiações como Beija-Flor, Mocidade Independente de Padre Miguel e Imperatriz Leopoldinense que, a partir de seus desfiles, apresentaram um novo modelo de fazer carnaval, mais voltado para o luxo visual (FERREIRA, 2004). 
publicações, visando dessa forma perscrutar não somente a inserção e o alcance dos periódicos pesquisados, mas os seus objetivos em explorar a temática carnavalesca. É importante ressaltar que a década de 1950 constituiu o auge da fotorreportagem no Brasil, advindo do crescimento da circulação de revistas ilustradas e do predomínio da fotografia na edição jornalística (PEREGRINO, 1991; SILVA, 2004a). Dessa forma, as imagens apresentadas pelos periódicos selecionados - produzidas na maior parte das vezes com a finalidade de satisfazer os interesses e as expectativas dos seus leitores - constituem indícios importantes para desvendar as representações das mulheres nos festejos carnavalescos do período.

Outro aspecto fundamental para a análise desse material é o conhecimento de seu público. Os periódicos $O$ Cruzeiro e Manchete atingiam um número significativo de leitores pertencentes principalmente às camadas médias urbanas e traziam como diferencial um grande número de imagens. É possível supor, pelos números dedicados à cobertura do carnaval e pela permanência desse tipo de reportagem nas revistas do gênero, que a temática momesca tinha forte apelo entre os leitores. O encaminhamento da reflexão sobre a temática em questão ampara-se, portanto, nas seguintes indagações: Como os periódicos representavam as mulheres que participavam dos bailes de salão e dos festejos carnavalescos de rua? Quais as diferenças ou semelhanças entre as representações de mulheres em ambas as festividades?

Considerando a conjuntura da época como um momento de mudanças importantes nos papéis das mulheres na sociedade, em relação a modos de se vestir, participação no mercado de trabalho e comportamentos, pretende-se inquirir sobre as representações ${ }^{5}$ construídas pela imprensa quanto a sua inserção nessas pândegas e os significados que foram demarcados sobre o seu modo de brincar os carnavais.

\section{As mulheres de elite e populares se divertem nos bailes e nos desfiles de rua dos carnavais da cidade}

As revistas $O$ Cruzeiro e Manchete se destacavam pela intensa cobertura dos carnavais, principalmente aqueles voltados às camadas médias e altas, que contavam na maioria das vezes com a presença de figuras de relevo nacional e internacional. Dessa forma, os jornalistas dessas revistas destacavam as festas realizadas em salões, como os do Teatro Municipal, do Hotel Copacabana, do Hotel Quitandinha e do Iate Clube, e tornavam-se comentaristas dos acontecimentos dos bailes. Outras modalidades de brincar o carnaval também eram cobertas pela imprensa ilustrada, principalmente os desfiles das escolas de samba que, no decorrer da década, passaram a ganhar mais espaço nas revistas. Contudo, os grandes bailes carnavalescos ainda eram o seu foco principal.

${ }^{5} \mathrm{O}$ conceito de representação, conforme pensado pelo historiador francês Roger Chartier, fornece subsídios para análise do material e da temática pesquisada neste artigo. $O$ autor considera que as representações, criadas pelos indivíduos ou grupos sociais para interpretarem e atribuírem sentido à realidade em que vivem, não são neutras, mas determinadas por interesses diversos.É importante salientar que para Chartier não existe representação sem um real que se deseja abarcar (CHARTIER, 1988). 
Um discurso muito comum nos anos 1950 era o de que o carnaval de rua estava em declínio, principalmente pelo crescimento dos bailes de salão, pela diminuição da presença de foliões nas avenidas centrais do Rio de Janeiro e pela intensificação da perda de prestígio de antigas modalidades de brincar o carnaval. As razões apontadas pela imprensa para o suposto arrefecimento do ânimo dos foliões e decréscimo do carnaval de rua encontravamse: a inflação, a descentralização dos festejos, a comercialização progressiva do carnaval, o aumento do número de espectadores em detrimento do número de foliões ativos, o uso de trajes cotidianos na composição das "fantasias" e a transformação dos costumes.

Neste período o carnaval de salão atingiu o seu ápice, não sendo exclusividade da elite, uma vez que os clubes esportivos e agremiações sociais e recreativas de bairros e subúrbios do Rio de Janeiro passaram a realizar igualmente essa forma de folguedo, razão pela qual o carnaval no período foi considerado descentralizado. Uma das inovações trazidas pelos periódicos da época, aplicada fortemente na cobertura do carnaval, foi a utilização do fotojornalismo, que consistia na presença de uma dupla "repórter-fotógrafo" para o registro dos principais eventos, permitindo que fossem apresentadas fotos dos desfiles das escolas de samba, dos ranchos, das grandes sociedades, dos bailes de salão e dos bailes à fantasia.

O sucesso dos carnavais da década de 1950, segundo os periódicos, estava relacionado, entre outros fatores, à presença de mulheres bonitas e sensuais, que se destacavam nos bailes por meio de fantasias que permitiam a exposição de suas pernas. No entanto, era ressaltada a disputa existente entre as mulheres mais velhas - as "balzaquianas" - e as mais jovens - os "brotinhos" - pela atração dos olhares do sexo masculino e pelo destaque nos bailes, classificação essa eivada de preconceitos embora travestida de supostas diferenças geracionais, em consonância com a percepção da indústria da publicidade em expansão no período. Os padrões estéticos associados às mulheres vistas como bonitas diziam respeito ao modelo de corpo representado, por exemplo, pela ganhadora do miss Brasil 1954, Martha Rocha. A “cintura fina, pés delicados, sorriso meigo e quadris largos" (SANT'ANNA, 2014, p. 101) integravam o rol de características de uma bela mulher e um pouco mais tarde o tipo corporal bronzeado. Esse padrão de beleza feminina estava relacionado, no entanto, às mulheres brancas que estampavam as propagandas da época. As mulheres negras tinham sua beleza afirmada nos concursos organizados pela imprensa negra que, com o passar do tempo, alcançaram visibilidade na imprensa em geral. Nesse tipo de concurso não era valorizado somente o aspecto físico da participante, mas seus gestos, conduta e educação, com o objetivo de se contrapor aos estereótipos arraigados na sociedade da época sobre a negra, que aparecia como inculta e sexualizada. ${ }^{6}$

Apesar de o carnaval constituir um momento libertador das hierarquias e proibições ${ }^{7}$, havia ainda nessas representações um moralismo quanto à participação de determinados

\footnotetext{
${ }^{6}$ É importante destacar o papel do Clube Renascença - criado em 1950 e frequentado pela elite negra do Rio de Janeiro na valorização da beleza das mulheres negras por meio da promoção de concursos e da preparação de suas misses para disputas até mesmo internacionais. (BRAGA, 2015, p.188).

${ }^{7} \mathrm{Na}$ obra A Cultura Popular na Idade Média e no Renascimento: o contexto de François Rabelais, o lingüista e marxista russo Mikhail Bakhtin desenvolveu a ideia de carnaval como quebra da ordem, compreendendo o folguedo praticado na Idade Média como momento em que havia a abolição temporária de todas as relações hierárquicas. (BAKHTIN, 1987).
} 
segmentos de mulheres, como as desquitadas, o que fica explícito no diálogo estabelecido entre um fotógrafo e um folião durante uma festa pré-carnavalesca de 1952: “- Não fotografe aquela moça de vestido floreado/ - Por quê? - Porque ela está se desquitando e não fica bem...” (GRACO, 12 jan.1952, p. 82).

Na década de 1950, as mulheres separadas, rotuladas como "liberadas", eram consideradas más influências para as casadas, razão pela qual estavam sujeitas a toda espécie de crítica social (BASSANEZI, 2002). É importante ressaltar que embora esse discurso também recaísse sobre as mulheres das classes populares, não tinha tanta ressonância porque estas eram independentes, considerando que sempre tiveram que trabalhar por uma questão de sobrevivência de si próprias e de suas famílias. Essa realidade certamente tornava os discursos que combatiam a participação das mulheres no mercado de trabalho e as uniões informais, sem muito efeito (VELLOSO, 1990), o que não significava a abolição dos preconceitos.

Os anos 1950 assinalaram mudanças significativas nas vestimentas utilizadas pelas mulheres nos folguedos carnavalescos, à medida que os foliões comuns manifestaram sua preferência por roupas mais leves, como shorts, blusas tomara que caia, baby dolls e vestimentas que pudessem expor as pernas e permitir às mulheres brincar de maneira mais descontraída o carnaval, ocasionando o progressivo abandono das fantasias ornamentadas, típicas de épocas passadas. Verificar-se-á que o fato de as fantasias usadas nesses festejos terem passado a ser descritas como minguadas é indicativo da maior ousadia do sexo feminino, que buscava no carnaval formas mais explícitas para extravasar a sua sensualidade. É importante assinalar que o disfarce compondo as fantasias ocupou um papel importante nas transgressões femininas manifestas em uma sociedade ainda extremamente conservadora e rígida. A reversão dessa postura, a partir da década de 1950, indicou atitudes de extravasamento quando acompanhadas por poses e condutas mais livres registradas pela imprensa, que selecionava as imagens com maior impacto visual.

Não obstante a perceptível disposição das mulheres a permitir-se flagrar em poses e comportamentos mais livres, é importante contrapor esse fato à interferência do fotógrafo no momento da realização da imagem. No carnaval, os fotógrafos registravam os momentos considerados mais significativos para transmitir uma determinada visão sobre os folguedos, de modo que escolhas eram feitas a partir de um conjunto de outras possibilidades. Para destacar-se entre as demais revistas, $O$ Cruzeiro recorreu a diversas formas de manipulação na cobertura do carnaval, como revelou posteriormente o diretor de redação do periódico, Accioly Netto:

[...] Contratávamos algumas garotas bonitas, que eram vestidas com fantasias mandadas fabricar por nós. Em determinado momento do baile, em pontos estratégicos do salão - onde se encontravam nossos fotógrafos -, as garotas apareciam, enquanto os flashes espoucavam, para logo desaparecer. Com isto, 
O Cruzeiro circulava mostrando gente bonita que nenhuma outra revista tinha tido tempo de focalizar (ACCIOLY NETTO, 1998, p. 136-137).

Os jornais e revistas expunham as fotografias como atestados de autenticidade daquilo que fora captado pelas lentes do fotógrafo, ou seja, como referenciais da própria realidade, quando muitas situações apresentadas nas fotografias eram o resultado de situações produzidas, e não flagrantes surpreendidos pela câmera. Além disso, o simples fato de saber que está sendo observado pela objetiva de uma máquina fotográfica pode provocar uma mudança de comportamento do sujeito, a fim de transmitir outra imagem de si (BARTHES, 1984). O fato de muitas fotos serem claramente posadas não significa uma ausência de transgressão e desnudamento por parte das mulheres que participavam dos festejos carnavalescos, pois, apesar da interferência do fotógrafo na sugestão de determinadas situações, as mulheres tinham consciência do grau de exibição ao qual estavam expostas, considerando a circulação das revistas. Outra evidência disso é que muitos comportamentos e vestimentas apresentados durante o carnaval eram considerados inapropriados e imorais pelos segmentos mais conservadores da sociedade da época, o que demonstra um clima de maior permissividade durante os folguedos. Essa situação também foi detectada nas décadas de 1920 e 1930, embora essas transgressões fossem mais sutis (SILVA, 2008).

Entre os diversos bailes realizados no Rio de Janeiro na década de 1950, na semana anterior ao carnaval e durante os três dias de festejo, alguns recebiam maior cobertura da imprensa: o dos Artistas, nos salões do Hotel Glória, na quinta-feira gorda; o do Copacabana Palace, nos salões do hotel, no sábado; e o tradicional Baile do Municipal, na segunda-feira. Os dois últimos constituíam espaços primordiais para o divertimento da elite, principalmente pelo fato de acontecerem em locais fechados, reservados em relação à multidão, e por cobrarem ingressos caros, o que acabava por barrar aqueles que não dispusessem de boas condições materiais.

Maria Isaura Pereira de Queiroz aponta as diferenças entre os bailes "fechados" e os "populares", afirmando que nos primeiros havia uma prévia escolha dos participantes, que incluíam autoridades, personalidades e outras figuras frequentes nas colunas sociais. Nos segundos, por outro lado, todos os que pudessem pagar os ingressos eram admitidos (QUEIROZ, 1992, p.125-126). A autora não discorre, contudo, sobre os bailes realmente populares, realizados nos salões dos subúrbios cariocas, não obstante sua importância na configuração do carnaval carioca na década de 1950.

Além de ser considerada uma festa tradicional e elegante, o carnaval do Municipal era visto como menos licencioso, e, por isso, passível de ser assistido por qualquer mocinha de família, embora trajes cada vez mais sumários começassem a aparecer, sem, contudo, predominar. Em contraposição, o Baile dos Artistas, realizado todos os anos no Hotel Glória, era conhecido pelo clima de maior licenciosidade, manifesto nas atitudes e nos trajes mais ousados, como biquínis e baby dolls, bem como no abuso das bebidas e do lança-perfume, que eram considerados responsáveis pelas constantes brigas. Este baile constituía um dos principais festejos pré- 
carnavalescos do Rio de Janeiro e atraía muitos jornalistas. O mesmo acontecia com o Baile das Atrizes realizado no Teatro João Caetano, conhecido pela coroação da rainha das atrizes, e que tinha como objetivo angariar fundos para o Retiro dos Artistas. Apesar da pouca roupa, durante a década de 1950, as mulheres ainda estavam vestidas. A completa nudez demorou aproximadamente vinte anos para tornar-se corrente nos carnavais brasileiros (QUEIROZ, 1992, p. 133).

Tendo em vista as colocações apresentadas anteriormente sobre os trajes carnavalescos, pertinentes ao carnaval carioca, e a fim de ressaltar o seu caráter mais livre e ousado, vale explorar alguns festejos momescos do período. É possível identificar duas situações diferentes evidenciadas nas fotografias a seguir, ambas datadas de 1953. A Figura 1 mostra o baile de elite do Teatro Municipal, em que os foliões aparecem trajados com roupas de gala, como smokings e vestidos de festa. Este baile costumava ser destacado pela elegância dos foliões, pelo maior "recato", pela ordem e pela profusão de fantasias. No entanto, o carnaval de 1953 foi descrito pela revista Manchete como fraco em relação aos anos anteriores em termos de animação e, principalmente, de fantasias utilizadas, em contraste às recomendações frisadas no convite: "a rigor ou fantasia de luxo, não sendo permitido em absoluto o branco para os cavalheiros" (ROCHA, 1953, p. 22).

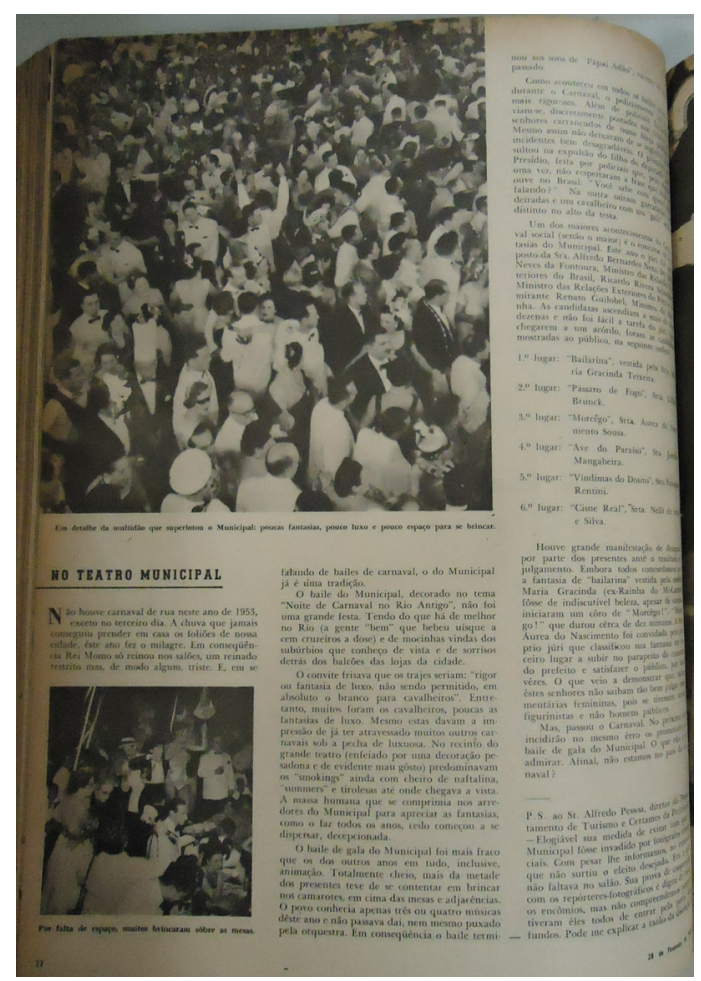

Figura 1 - Grupo de foliões no tradicional Baile do Teatro Municipal, em 1953

(ROCHA, 1953, p. 22). 
Já na Figura 2, é possível perceber uma maior liberdade e permissividade da foliã em um festejo pré-carnavalesco de 1953. A fotografia foi acompanhada da seguinte legenda: "A dúvida no baile era saber se esta jovem já entrou no baile tarada ou si ficou depois". O termo utilizado para se referir a garota é uma referência ao nome do próprio bloco carnavalesco, denominado "Os Tarados", que pela primeira vez em 1953 organizou bailes pré-carnavalescos e carnavalescos. O bloco foi criado por um grupo de rapazes de classes média e alta residentes em Copacabana, que tinham como objetivo promover bailes animados, em que fosse possível a total entrega "ao sereno, às bebidas e, principalmente, às mulheres". O convite do baile era capaz de "impressionar a moral mais elástica", segundo a revista Manchete, uma vez que apresentava os seguintes dizeres: "Um grupo de tarados espera a sua desprezível pessoa, sexta-feira, às 23 horas, (não foi identificado) do manicômio" (OLIVEIRA, 1953, p. 38).

O próprio emblema do grupo - um lobo descabelado, de dentes pontudos, babando lascivamente diante de uma mulher de seios descobertos - demonstra o propósito da festa e a forma como a mulher era representada: uma presa para os homens. Dessa forma, o grupo deixava claro as suas intenções de libertinagem durante os festejos, que foram descritos como animados e sem confusões. Essa Figura (2) apresenta uma moça trajada como heroína, com as pernas à mostra - característica típica das fantasias do período - e com uma postura que demonstra alegria e descontração.

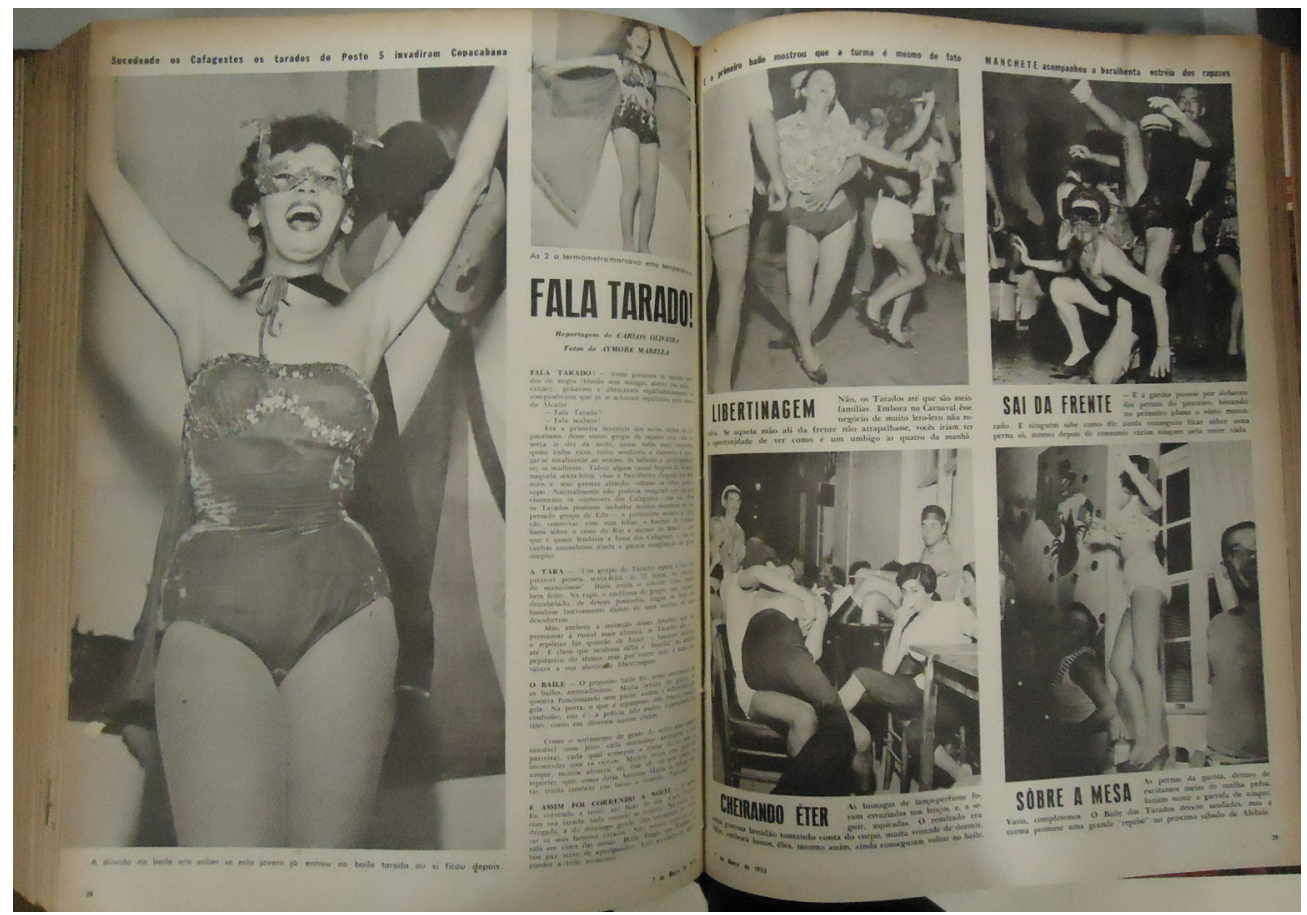

Figura 2 - Foliona no Baile dos Tarados, em 1953

(OLIVEIRA, 1953, p. 38). 
Verifica-se que o carnaval realizava-se de maneira diversa conforme o local e o grupo social a que era destinado. Nesse sentido, é visível uma distinção entre ambas as fotografias, pois, enquanto a primeira é típica de um festejo em um espaço de elite, a segunda denota um clima de maior liberdade e extravasamento. Apesar do aparente desnudamento apresentado na imagem acima, é importante ressaltar que as fotografias de imprensa não são simples registros de um acontecimento, já que há interesses implícitos como do fotográfo, da revista e do próprio público. A produção de uma fotorreportagem é um processo que envolve: (1) a seleção da foto, determinada pelo acontecimento a ser retratado, e que requer escolhas técnicas; (2) o trabalho do editor de fotografia, que seleciona entre as imagens registradas aquelas que vão ser publicadas; e (3), por último, a editoria geral, que determina o espaço que as fotografias selecionadas vão ocupar junto ao texto na revista (PEREGRINO, 1991, p. 45-46).

A cobertura realizada pelas revistas ilustradas a respeito do carnaval foi questionada pelo jornal Correio da Manhã, que, em matéria publicada em 1953, criticou a forma como os festejos carnavalescos eram apresentados pelas revistas desse gênero, afirmando haver, segundo o seu ponto de vista, um exagero daquilo que realmente acontecia durante o carnaval. Assim, publicou que:

O Carnaval das revistas ilustradas - quero dizer das estampas que o rememoram nos periódicos - é talvez mais livre, mais desabotoado, mais nu que os das ruas e bailes [...] abuso da reportagem leva à fixação de poses lascivas, que muitas vêzes nem são espontâneas, porque determinadas pela presença do fotógrafo ou por este sugerida. [...] fazemos do Carnaval uma idéia lamentável, atribuindolhe sinal de ampla dissolução dos costumes, quando, bem examinadas as coisas, estas cenas constituem meros acidentes, não espelham a índole do povo. Sim, não espelham a índole de um povo devotado à família, como instituição que se encontra na base de sua vida. Ganham todavia o prestígio da publicidade, insinuando-se qual se fôssem a regra e não a exceção (REGO, 1953, p. 04).

Neste discurso é negado o caráter libertador e subversivo do carnaval, uma vez que as poses apresentadas pelos foliões são colocadas como exceções que não deveriam receber maior atenção da imprensa. O jornal reitera, ainda, o papel da família como sustentáculo da vida e como valor moral presente inclusive no carnaval.

Algumas fantasias fundamentais em qualquer baile carnavalesco - como as de arlequim - figuraram entre os foliões na década de 1950, embora tenham adquirido estilos diferentes, como é possível perceber na imagem selecionada a seguir. 

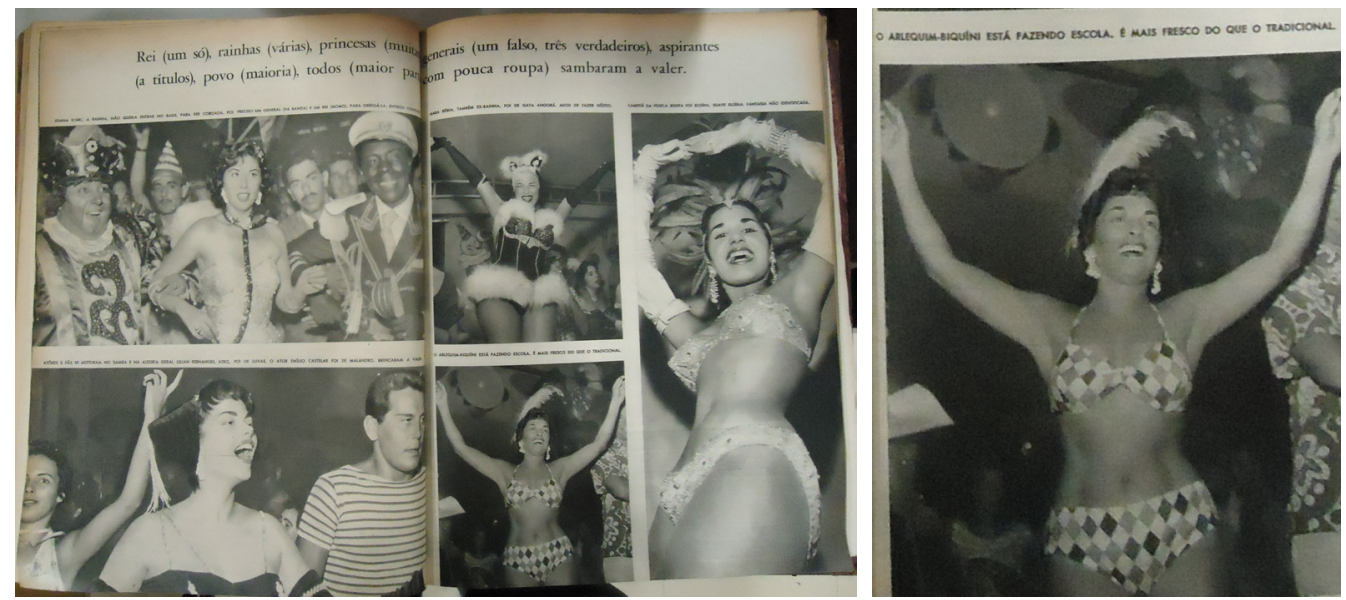

Figura 3 - Arlequim estilizado no Baile das Atrizes, em 1958 (ATRIZES..., 1958, p. 09).

Na Figura 3, datada de 1958, a foliona veste uma fantasia de arlequim, caracterizada por losangos multicolores, em formato de biquíni, conforme descrição da própria imprensa. São perceptíveis mudanças nos trajes carnavalescos apresentados pelas mulheres ao longo do carnaval, como demonstra o fato de essa foliona comparecer ao baile usando um "biquíni", mesmo em se tratando do Baile das Atrizes, embora tal roupa de banho fosse ainda exceção no período.

No Baile do Municipal, de 1959, foi possível perceber um maior despojamento nas posturas femininas. Neste, duas garotas chamam atenção de todos à sua volta com a sua animação ao subir em cima de cadeiras para brincar e cantar (Figura 4).
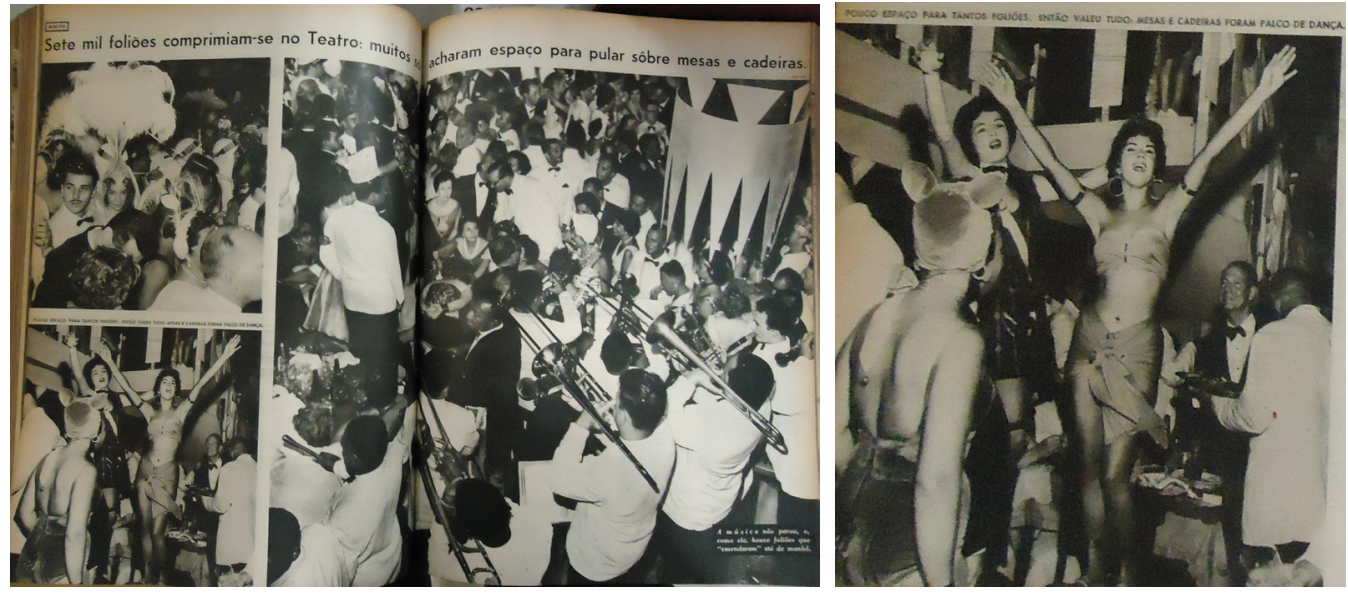

Figura 4 - Grupo de mulheres no Baile do Municipal de 1959

(O CONCURSO..., 1959, p. 42). 
Vale destacar que o carnaval de 1959 do Municipal foi descrito pelos periódicos como um verdadeiro sucesso, no entanto, a revista $O$ Cruzeiro destacou com pesar a presença de algumas mulheres com poucas roupas naquele evento da elite, afirmando que:

[...] no mundo maravilhoso de cetim, pérola e fios de ouro e prata [...] temos a registrar a pobreza de imaginação de muitos foliões, que não souberam corresponder à noitada de gala. É o caso de duas "Noivas", de véu, grinalda... e biquíni, que nossas objetivas não fixaram, pois atentavam contra o sagrado instituto do casamento (MUNICIPAL..., 1959, p. 09).

Neste comentário fica perceptível que mesmo em se tratando de uma festa carnavalesca, determinados comportamentos e trajes eram vistos como inadequados, sobretudo no pomposo Baile do Municipal. Na afirmação do jornalista, percebe-se a visão conservadora da época a respeito do casamento, expressa por meio da censura à transgressão da pureza e da sacralidade do matrimônio manifestado nos trajes das mulheres, que eram contrários ao ideal de recato e inocência esperados de uma noiva. Tal manifestação demonstra o desejo feminino de zombar de determinadas características do casamento, como evidências das mudanças pelas quais passava o papel da mulher na sociedade, enquanto a afirmação do jornalista demonstra o receio de que essa instituição, considerada base da sociedade, fosse maculada e com ela os princípios cristãos defendidos pela Igreja Católica.

Nesse sentido, moças com roupas sumárias como aquelas presentes no baile de 1959, do Municipal, não correspondiam ao esplendor esperado em tal celebração momesca. $O$ uso de roupas de banho como fantasia, mais comum nos Bailes das Atrizes e dos Artistas, não provocava excessivo estranhamento na imprensa e no público leitor, que já aguardavam esse tipo de comportamento, reafirmando o preconceito voltado a esse segmento artístico.

Neste período, as mulheres passaram a ocupar mais o espaço público e a deixar o corpo mais descoberto, explorando principalmente a sensualidade no uso de determinadas roupas, embora vivessem ainda em uma sociedade conservadora e machista. As revistas, no entanto, souberam aproveitar essas transformações para apresentar imagens de maior impacto visual, principalmente aquelas em que as mulheres apareciam em situações mais livres.

No que se refere ao carnaval popular, é importante frisar que as mulheres estiveram presentes desde o surgimento das escolas de samba, considerando o papel desempenhado pelas chamadas "tias" no surgimento dos blocos carnavalescos - embriões das futuras escolas de samba. Com o desenvolvimento dessas agremiações, as mulheres passaram a ocupar outros postos, como o de porta-bandeira e a ala das baianas (SIMSON, 1991/1992, p.18). A participação de muitas "matriarcas do samba" nos desfiles e ensaios das escolas era fator importante de coesão e de proteção do grupo. Tal fato pode ser aferido em depoimentos como este, datado de 1958, durante a cobertura de um ensaio do Império Serrano: 
O ensaio da Império Serrano talvez seja o que mais impressiona [...] O ensaio começa em geral às 10 em ponto. É tempo em que Dona Marta, espécie de mãede-santo e a mais antiga fundadora da escola, sobe. É recebida à porta pelo presidente e autoridades [...] ela vai ao "pegi", onde acende duas velas aos pés de São Jorge. Reza. As baterias, que nunca pararam de tocar, de repente troam mais fortes. Aparecem cabrochas de todos os lados. Vai começar (LEMOS; DAMATA, 1958, p. 58).

Verifica-se também a combinação entre manifestações religiosas e profanas nas exibições das escolas de samba, sendo que o local dos ensaios era chamado de terreiro, termo idêntico ao do lugar onde eram realizados os cultos afro-brasileiros por permitiremà articulação defestas, encontros e reuniões de confraternização. De maneira semelhante ao antigo desfile dos ranchos, em que "tias" eram solicitadas a dar suas bênçãos aos foliões antes da folia (VELLOSO, 1990, p. 215), no ensaio do Império Serrano, percebe-se o papel de Dona Marta, uma das fundadoras da escola, que no início dos ensaios pede proteção a São Jorge, figura cultuada no candomblé e na umbanda.

A ginga e a suposta sensualidade das mulheres dos morros cariocas também foram aspectos abordados pelos periódicos, embora seus esforços fossem mais ressaltados nas matérias referentes às agremiações carnavalescas. $O$ samba considerado fator determinante na manifestação da sensualidade das mulheres pode ser verificado em diferentes anos na cobertura da imprensa, como demonstram estas frases da revista O Cruzeiro de 1953: "Reboleando o corpo num mar de ritmo as mulheres do morro dignificaram o melhor carnaval no mundo" (FERREIRA, 1953a, p. 17) e "As cabrochas tinham ares de rainha, abanavam-se em leques rendados e rodopiavam com requebros graciosos ao som dos atabaques" (FERREIRA, 1953b, p. 06). Tal aspecto também foi ressaltado pela revista Manchete, em matéria de 1956: “A marcação do tamborim repercute na alma delas e o corpo ginga” (O CARNAVAL...,1956, p. 30).

As inferências da imprensa sobre a sensualidade das mulheres das classes populares que desfilavam nas escolas de samba mostravam-se ainda sutis, na comparação com a carga de sensualidade e erotismo que seria atribuído à figura da mulata em meados dos anos 1960 e sobretudo na década de 1970, quando a palavra mulato "praticamente viria a substituir o termo negro" na mídia impressa (BRAGA, 2015, p. 200). O mesmo pode-se afirmar em relação ao carnaval e a sua cobertura, na qual a figura da mulata ganharia uma conotação ainda mais lasciva - acompanhando o próprio processo de espetacularização dos folguedos - passando a incorporar nessa representação o erotismo da festa. ${ }^{8}$

\footnotetext{
${ }^{8}$ É importante ressaltar que os estereótipos comumente atribuídos à figura da mulata - sexualidade impulsiva e exacerbada - relacionam-se ao passado escravocrata brasileiro, no qual as mucamas eram vistas como objetos sexuais de seus senhores, tendo esse tipo de representação permanecido no imaginário social mesmo quando outros sentidos foram associados a essa figura na primeira metade do século XX, relacionados à sua transformação em símbolo da brasilidade mestiça no processo de construção da identidade brasileira ainda durante o Estado Novo. (ABREU, 2000).
} 
A respeito das representações relacionadas às porta-bandeiras, em 1958, duas escolas tiveram problemas com as ocupantes dessa posição: a Portela e a Mangueira. As representantes de ambas as escolas casaram e não sabiam se poderiam desfilar, uma vez que os seus respectivos maridos apresentavam resistência em aceitar a continuação das mesmas nas agremiações (LEMOS; DAMATA, 1958, p. 59). É válido notar o fato de que, mesmo pertencendo à "Ala dos Impossíveis" da mesma escola de samba que a esposa - a Portela - o marido de Vilma enxergava problemas em sua participação como porta-bandeira. Apesar dos protestos do cônjuge, Vilma desfilou em 1958, quando já estavam casados, e no ano seguinte mais uma vez teve que lidar com os protestos do marido, desta vez em razão do nascimento da filha do casal. Segundo a revista $O$ Cruzeiro, a possível desistência do posto de porta-bandeira se daria pelas novas responsabilidades assumidas por Vilma dentro do âmbito doméstico e pelo alto custo das fantasias (VASCONCELOS, 1959, p. 48), em torno de oito mil cruzeiros, podendo chegar a 30 mil no caso dos principais figurantes.

Não obstante as dificuldades encaradas pelas folionas, a proibição do marido de Vilma não teve respaldo da própria protagonista que continuou desfilando pela escola, tornando-se uma celebridade. Se por um lado, pode significar a visão do periódico que impõe acomodação desse segmento às regras existentes na sociedade mais geral, segundo as quais a mulher deveria exercer prioritariamente o papel de dona de casa, esposa e mãe, por outro, a postura assumida pelo marido de Vilma deve ser compreendida em um contexto mais amplo, considerando o esforço realizado pela imprensa negra nas décadas de 1930 e 1940, principalmente, na definição de uma identidade para as mulheres negras. Essa perspectiva seria em grande medida calcada nos padrões de moralidade da época, nos quais os ditos papéis tradicionais eram muito valorizados ao passo que se procurava contrapor essa imagem à da "mulata fácil", construída no período da escravidão e ainda presente na sociedade dos anos 1950.

É preciso compreender ainda, no âmbito dessa discussão, que as mulheres negras sempre tiveram que trabalhar para garantir o sustento de seus filhos e família, tendo muitas vezes que assumir sozinhas o cuidado da prole e de seus lares, além de aceitarem muitas vezes, em razão das circunstâncias, uniões afetivas informais, nas quais separações e rearranjos eram comuns. Na tentativa de modificar a visão que se tinha em relação à figura da mulata, associações ligadas a grupos negros afirmavam a necessidade de se manter um estilo de vida honroso, procurando escapar assim aos estereótipos tão vinculados à presença das mulheres no carnaval, por exemplo. (BRAGA, 2015).

Quanto à inserção feminina nas atividades das escolas de samba, além daquelas relacionadas propriamente ao desfile carnavalesco, envolvendo os postos de porta-bandeira e passista, a historiografia sobre o tema forneceu alguns indícios. Se é inegável a projeção assumida pelas mulheres durante os desfiles das escolas de samba, ainda que não adquirissem igual prestígio perante a imprensa e a própria escola, havia restrições à participação feminina em cargos de direção nas escolas de samba, por exemplo, que na interpretação de Olga Simson foram 
camufladas ao longo do desenvolvimento dessas agremiações pela valorização de mulheres jovens e bonitas no espetáculo visual carnavalesco (SIMSON, 1992, p. 31).

Rompendo preconceitos, Dona Ivone Lara, tornou-se a primeira mulher a integrar uma ala de compositores de sambas-enredos, a do Grêmio Recreativo Escola de Samba Império Serrano, em fins dos anos 1940, considerando que a composição de sambas era prerrogativa do gênero masculino. No entanto, o talento de Dona Ivone como compositora enfrentou barreiras e suas composições, a seu pedido, eram apresentadas para outros sambistas pelo primo, Mestre Fuleiro, compositor e figura importante da Prazer da Serrinha, como se fossem de autoria dele, em razão do preconceito que havia em relação à mulher sambista. Dona Ivone ${ }^{9}$ era também nora de Alfredo Costa, então presidente da Prazer da Serrinha (BURNS, 2007). É importante notar nesse exemplo que a aceitação de mulheres em determinadas posições, como a de compositora, não se dava somente pela manifestação de seu talento, mas pelas relações estabelecidas entre o próprio grupo, demonstrando o machismo existente na época dentro do universo do samba.

É importante ressaltar, no que se refere ao período tratado neste artigo, a presença da temática afro-brasileira nos enredos de algumas agremiações cariocas, como: Quilombo dos Palmares (Salgueiro, 1960) e Casa-Grande e Senzala (Mangueira, 1962). Os anos subsequentes foram acompanhados pelo aumento dos desfiles que abordaram essa questão, seja pela alusão ao cotidiano dos escravos no período colonial, as resistências e lutas pela liberdade, ou pela valorização das práticas culturais negras (FARIA, 2016) ${ }^{10}$. A temática negra, embora estivesse presente anteriormente à década de 1950, não foi considerada por alguns estudiosos como representativa desse universo. Monique Augras, por exemplo, considera os sambas anteriores aos do Salgueiro, a contar de 1954, com Uma Romaria na Bahia, pouco significativos na alusão da temática negra, por carecerem de referências mais diretas ao conteúdo. O Salgueiro ao trazer um enredo exaltando a Bahia como "terra do samba, de gente bamba e do candomblé" inaugurou, na interpretação da pesquisadora, a presença da negritude no samba-enredo, que se faria presente também em carnavais de anos subsequentes (AUGRAS, 1998). Nesse sentido podem-se citar os enredos que abordaram tal temática na década de 1950: Uma Romaria na Bahia (Salgueiro, 1954), Navio Negreiro (Salgueiro, 1957) e Viagens pitorescas através do Brasil Debret (Salgueiro, 1959).

\footnotetext{
${ }^{9}$ Os textos que relatam a trajetória de Dona Ivone Lara não esclarecem o momento em que ela passou a assinar, de fato, os seus sambas. É informado que, em 1947, ano em que se casou com o filho do presidente da Prazer da Serrinha, compôs o samba "Nasci pra sofrer", que teria marcado o estreitamento das suas relações com alguns sambistas da agremiação que, naquele ano, formaram a Império Serrano. Em 1965, no entanto, compôs um samba-enredo oficial, chamado "Cinco bailes da história do Rio", em parceria com Silas de Oliveira e Bacalhau, para a agremiação Império Serrano, notabilizando-se como a primeira mulher a ter o seu nome inscrito nesse universo (BURNS, 2007). Os indícios sugerem que Dona Ivone passou a assinar os seus sambas somente quando se sentiu confiante para tanto - sabedora do sucesso que estes faziam quando apresentados pelo primo - e amparada pelas relações familiares estabelecidas com pessoas reconhecidas na agremiação, na tentativa de fugir da discriminação que possivelmente sofreria por ser mulher em um meio marcadamente masculino e machista.

${ }^{10}$ Alguns enredos demonstram o prosseguimento da presença da temática negra no período: Exaltação à Bahia (Mangueira, 1963), Chica da Silva (Salgueiro, 1963), Chico Rei (Salgueiro, 1964), História de um Preto Velho (Mangueira, 1964), Glórias e Graças da Bahia (Império Serrano, 1966) e Bahia de Todos os Deuses (Salgueiro, 1969), entre outros.
} 
No entanto, as escolas de samba, associações populares de origem negra, passaram a atrair já na década de 1950 pessoas das classes médias para os seus ensaios e desfiles, acabando por integrar profissionais desse segmento social e, nos anos 1960, artistas pertencentes em sua grande maioria à Escola de Belas Artes ${ }^{11}$. Guilherme José Motta Faria (2016) demonstra em seu artigo "As escolas de samba do Rio de Janeiro nos anos 60 e as narrativas sobre a história do negro na avenida", o papel dessas agremiações carnavalescas na construção de uma "versão da história do negro no Brasil", ainda que não contassem com reconhecimento da historiografia do movimento negro. O autor salienta, a partir da análise desses sambas-enredos, a importância que essas agremiações carnavalescas tiveram no levantamento de discussões acerca da história de homens e mulheres negras. Não desconsiderando, evidentemente, a relevância desses sambas na afirmação da história dos negros no Brasil, há indícios sobre a existência de relações desiguais e hierárquicas entre os gêneros no cotidiano dessas agremiações e as dificuldades que muitas mulheres enfrentavam em seus relacionamentos amorosos no que se referia à participação nos desfiles e nas atividades carnavalescas, embora conquistas nesse âmbito também estivessem ocorrendo.

Em depoimento para o Museu da Imagem e do Som do Rio de Janeiro, Rivailda do Nascimento Souza, mais conhecida como Mocinha, antiga porta-bandeira da Mangueira, revelou as dificuldades que encontrou para continuar desfilando na agremiação após o casamento e o nascimento dos filhos. O retorno à agremiação, em 1960, ocorreu após o presidente da escola da época, Roberto Paulino, convencer o marido de Mocinha, comprometendo-se a pagar a fantasia utilizada por ela nos desfiles, além da sogra garantir o cuidado dos filhos do casal no tempo em que Mocinha estivesse envolvida com as atividades da agremiação. Neste mesmo depoimento Mocinha relata que o marido não gostava de carnaval, mas de "fazer presença" com suas fotografias, que apareciam nas reportagens de Manchete e O Cruzeiro (SOUZA, 2000). É possível inferir que o marido de Mocinha aceitou de forma mais contundente a sua participação no carnaval, a partir do momento que ela ganhou visibilidade com o posto e também oportunidades de trabalho.

É importante assinalar que, para além das funções habituais exercidas pelas porta-bandeiras no espaço cotidiano, sempre lembradas pelas revistas ilustradas e contrapostas ao tempo do carnaval, destaca-se o fato de que muitas dessas mulheres tiveram suas vidas transformadas também no âmbito ordinário em virtude do carnaval. Vilma, por exemplo, notabilizada por ocupar o posto de primeira porta-bandeira da Portela, antes mesmo de participar da escola já se apresentava nos espetáculos de Carlos Machado (grande nome no universo dos espetáculos cariocas) empunhando uma bandeira de escola de samba. Mocinha também usou

\footnotetext{
${ }^{11}$ Não obstante tivessem atraído pessoas da pequena e média burguesia para seus desfiles, a composição étnica das escolas de samba ainda continuava majoritariamente negra e "mulata", termos estes usados nas pesquisas consultadas por Queiroz sobre as escolas Mangueira e Padre Miguel no período posterior ao abordado neste artigo, mas que demonstram que essas agremiações eram negras, embora a autora tenha ressaltado a predominância branca nos espaços de poder (QUEIROZ, 1992).
} 
da fama adquirida na Mangueira, em um período de internacionalização do carnaval, para se apresentar em eventos e shows. No entanto, tal assunto precisa ser melhor investigado pela historiografia.

No que se refere especificamente às escolas de samba, ao contrário da cobertura sobre os festejos de salão, em que os destaques eram o luxo das fantasias e a ousadia das roupas das folionas, as matérias dos periódicos citados concernentes a essas agremiações, ressaltavam a disciplina dos seus componentes para produzir o que era considerado o principal espetáculo do carnaval de rua. Além disso, o papel desempenhado por essas mulheres nas agremiações foi constantemente destacado, desde o início dos anos 1950, principalmente ao assumirem as posições de pastora, porta-bandeira e baiana, como fica evidenciado no trecho a seguir, de $O$ Cruzeiro, a respeito do posto de porta-bandeira:

A cabrocha eleita para tal posto desfruta de uma posição privilegiada e em torno de sua figura eleva-se um certo respeito e até mesmo uma mística [...] a prova de que elas julgam honrosa a posição que ocupam, está no fato de quando eleitas têm que arcar inteiramente com as despesas para a confecção de um luxuoso traje do qual consta um manto de grande beleza [...] (BARRETO, 1951, p. 116-117).

Por mais que a palavra mulata já se fizesse presente há tempos na imprensa, na literatura e nas canções populares e constar na cobertura carnavalesca das revistas ilustradas, não aparecia, nesse contexto, tão recorrentemente em comparação com as décadas subsequentes, na qual estará estritamente relacionada ao carnaval e ao erotismo da festa. No trecho acima o termo "cabrocha" foi utilizado para se referir especificamente a porta-bandeira, no entanto, costumava-se empregar o mesmo para as mulheres em geral que sambavam e se apresentavam nos desfiles das escolas de samba e, outrora, para designar as pastoras (LOPES; SIMAS, 2015). A palavra relaciona-se no seu sentido mais amplo a mulher mestiça jovem, muitas vezes associada à figura da mulata, sem trazer a carga sexual implícita deste último termo.

Ainda sobre a figura da porta-bandeira, a revista $O$ Cruzeiro, em 1959, traz a sucinta biografia de Neide Francisco Gomes como representativa do empenho para não perder o posto de portabandeira na Estação-Primeira:

Neide Francisco Gomes é lavadeira durante 362 dias. Nos outros três, Neide é outra pessoa. Uma pessoa altamente importante: é porta-bandeira da famosa escola de samba da Mangueira "Estação Primeira". O seu carnaval é tirado da roupa que lava. Um carnaval suado, de duro batente. No ano passado (1958) [...]“Guardou” na Caixa Econômica um cordão de ouro, um anel e um relógio. E mais a sua querida radiola [...]. Este ano ela não tinha mais nada para torrar. Mas, com os seus trabalhos, já conseguiu depositar quatro mil cruzeiros no fundo do baú (VASCONCELOS, 1959, p. 48). 
O caso de Neide ilustrava, de acordo com a imprensa, a vida de tantas outras mulheres que assim como ela demonstraram persistência para conseguirem desfilar na sua agremiação favorita, muitas vezes sem se importarem com o fato de estarem grávidas ou amamentando. Se o esforço dessas mulheres para participar do carnaval era sempre ressaltado nessas ocasiões festivas, com realce para sua vida de privações, mas abstraídas dos preconceitos e racismo que atingiam as mulheres negras em geral, as demais mulheres do grupo, que tinham um cotidiano semelhante, não eram destaque no carnaval, embora algumas de suas mazelas estivessem presentes no noticiário da época. Silvana Louzada da Silva salienta, no entanto, o apagamento da figura do negro pelas revistas Manchete e $O$ Cruzeiro no projeto que estas tinham de construir uma identidade brasileira, pautada na busca de um repertório comum, capaz de reforçar a "coesão interna, o sentimento de pertencimento, possibilitando a cada brasileiro [...] uma inédita intimidade com o restante da nação" (SILVA, 2004a, p. 144). Índios e negros foram renegados neste intento, sendo referenciados em muitas matérias como os "outros", não como parte do "nós", revelando o preconceito e a exclusão provenientes do período colonial e da escravidão. ${ }^{12}$

Quanto aos folguedos momescos é perceptível o comprometimento das revistas ilustradas com a ideia de carnaval como momento de inversão da ordem, na qual a vida cotidiana das mulheres negras que atuavam como porta-bandeiras era contraposta ao tempo da folia. $\mathrm{O}$ mascaramento da pobreza ${ }^{13}$ demonstrado pelas revistas ilustradas como forma de não macular a imagem que se queria construir do Brasil, aparecia também nas coberturas carnavalescas, já que o carnaval, constituído em principal festividade brasileira, tinha nas escolas de samba a sua principal atração e os negros como seus representantes. Neste contexto, portanto, os negros eram exaltados no sentido da valorização dos seus esforços na produção da festa, na arrecadação de recursos que possibilitassem a sua participação nos desfiles, em uma clara demonstração da excepcionalidade da festa, considerando o retorno de muitas dessas pessoas as suas ocupações habituais após a folia. É possível conjecturar que os negros das escolas de samba ganharam destaque nas revistas pela representatividade cultural que alcançaram junto às agremiações que criaram.

Nesse sentido, o papel de porta-bandeira era valorizado, e, mesmo que na maior parte das escolas de samba esse posto fosse ocupado por mulheres conhecidas e de participação tradicional, sempre existia a possibilidade de serem substituídas por outras consideradas melhores para a posição, a depender da opinião da diretoria quanto à manutenção ou não da mesma mulher no posto.

O início dos anos 1960 não assinalaria mudanças significativas nos papéis das mulheres na sociedade brasileira, embora algumas mudanças já estivessem ocorrendo, relacionadas

\footnotetext{
${ }^{12} \mathrm{~A}$ autora destaca que as matérias com teor de denúncia social publicadas pelo $O$ Cruzeiro se deviam ao interesse pessoal dos repórteres e não como parte do projeto editorial e de país da revista.

${ }^{13} \mathrm{Em}$ depoimento para Silvana Louzada da Silva, Juvenal Pereira, ex- fotógrafo de $O$ Cruzeiro, revelou a forma como o negro e o pobre deveriam ser retratados quando da impossibilidade de "eliminá-los" da cena: "Quando você for fotografar uma favela, fotografe a casa mais arrumada, quando você fotografar um negro fotografe o mais limpo e bonito". (SILVA, 2004a, p. 152)
} 
sobretudo ao papel de destaque social assumido pelos jovens. O surgimento da pílula anticoncepcional, nos primeiros anos da década de 1960, contribuiu para as mudanças nos padrões de comportamento das mulheres, mas estas foram sentidas somente na segunda metade dos anos 1960 (BASSANEZI, 1992).

Nas celebrações carnavalescas, comportamentos que ainda eram objetos de críticas no cotidiano ganhavam expressão, como, por exemplo, a manifestação da sensualidade feminina e o desnudamento (mesmo que parcial) de seu corpo em um ambiente exterior ao da praia. As instruções do Chefe de Polícia para o carnaval, publicadas nos jornais da época ${ }^{14}$, demonstram mudanças nas vestimentas usadas pelas mulheres nos festejos, as proibições e a própria modificação nos costumes. Os biquínis passaram a aparecer em maior quantidade nos festejos carnavalescos, como já assinalado anteriormente, representando as preferências das folionas, ao passo que as interdições da polícia aumentavam. Em 1962, contrariando a proibição do biquíni e do uso do lança-perfume no carnaval, algumas mulheres compareceram ao baile do Hotel Copacabana Palace vestindo "trajes sumários", conforme a descrição de O Cruzeiro:

Embora o lança-perfume, entre outras proibições esquecidas, como a dos trajes sumários, tenha sido vetado, vez por outra tropeçava-se nos frascos metálicos ainda rescendentes ao éter cheirado às escondidas[...]. A proibição dos trajes sumários não foi levada a sério e, antes que as autoridades o notassem, as garotas se descobriram à vontade, num carnaval realista (VASCONCELOS; ROCHA; RUDGE; SOLARI; VIOLA; ALFREDO; PASSOS; AUDI, 1962, p.123-129).

O desnudamento parcial do corpo feminino, possibilitado pelo uso de biquínis, foi a estratégia usada pelo GRES Acadêmicos do Salgueiro para representar na avenida as mulheres indígenas necessárias no enredo "Descobrimento do Brasil", de 1962, no qual "índias mulatas" vestindo biquínis estilizados - com a presença de penas - e usando acessórios que remetiam à cultura indígena, tornaram-se motivo das críticas que envolveram o julgamento da agremiação:

[...] Com perto de 1.500 figuras, a vermelho e branco vinha "Descobrindo o Brasil" e trazia muitas atrações nas suas alas, como a Fabulosa Paula [...] e as mulatas de Mercedes Batista, vestidas de índias, assunto de discussão para os que se encontravam na Rio Branco. Quando alegaram que elas estavam seminuas, o mestre-sala Casemiro "Calça-Larga" saiu em sua defesa: - "Índia é assim mesmo, com pouca roupa" (MORAES; AUDI; PASSOS; LUIZ, 1962, p. 143).

\footnotetext{
${ }^{14} \mathrm{Em}$ 1957, a proibição do maiô ainda aparecia em destaque nas instruções policiais (ENTRAM...,1957, p.02), em 1961, por sua vez, o jornal $O$ Globo, ao divulgar as medidas a serem tomadas durante o carnaval daquele ano, já explicitava de forma enfática no título da matéria a proibição do biquíni nos festejos, com os dizeres: "Fantasia, sim; Biquíni, não!" (FANTASIA...,1961, p. 09).
} 
No excerto acima já é a palavra mulata que aparece para denominar as passistas que compunham a ala das índias no desfile mencionado. Embora ainda não predominassem nos festejos de rua e de salão, neste período os biquínis adquiriram relevância na composição de fantasias diversas, que passaram a ganhar cada vez mais destaque nas revistas ilustradas. As representações da imprensa sobre as mulheres brincantes nos festejos momescos se direcionariam gradativamente para uma leitura menos refinada da manifestação da sensualidade feminina, deixando de insinuar para expor mais claramente este elemento que, em menor proporção, já fazia parte dos carnavais passados.

\section{Considerações finais}

Pode-se dizer que o carnaval, a principal festa brasileira, constitui um assunto de ampla repercussão e mobilização nacionais, razão pela qual foi alvo de intensa cobertura pela imprensa nos anos dessa investigação. Esse interesse pelo carnaval tornava grande a procura por informações sobre os festejos nos periódicos do período; assim, as revistas O Cruzeiro e Manchete procuravam trazer imagens e reportagens capazes de atrair a atenção de leitores, e chegavam a publicar edições praticamente inteiras dedicadas aos folguedos. Havia uma competição entre elas pelas melhores coberturas, que privilegiavam os bailes carnavalescos voltados às classes média e alta, e, com menor ênfase, os desfiles das escolas de samba, blocos e outras modalidades carnavalescas. É importante assinalar, no entanto, que as escolas de samba vinham adquirindo mais espaço na cobertura dessas revistas, ao passo que a sua relevância foi aumentando ao longo do período abordado neste artigo.

No que se refere especificamente ao modo como as mulheres brincaram o carnaval, ao menos nas representações da imprensa, é perceptível a liberdade encontrada durante a realização dos folguedos para manifestação de comportamentos que não seriam facilmente aceitos se fossem flagrados no cotidiano. Este fato é comprovado pelas fotos registradas pela imprensa, demonstrativas da ousadia das mulheres no uso de determinadas vestes que poderiam expressar a sensualidade por meio do desnudamento de determinadas partes do corpo, como as pernas e a barriga.

Os anos selecionados, de forma especial, marcam um período de transição, inclusive no papel da mulher na sociedade, em que houve o prenúncio de diversas mudanças que se consolidariam em décadas posteriores, em relação a comportamentos, modo de se vestir e participação no mercado de trabalho. Em relação às mulheres negras, vale salientar que a sua erotização ocorrerá de fato no período posterior ao analisado, acompanhando de certa forma a comercialização e a espetacularização dos desfiles das escolas de samba e o apelo sexual que o corpo feminino passará a adquirir na época. No entanto, no período aqui analisado, foi o esforço das mulheres para comprar suas fantasias e participar dos desfiles das escolas de samba que ganhou destaque na imprensa. 
Não obstante essa especificidade, as percepções do real empreendidas pela imprensa quanto à presença feminina nos folguedos momescos, demonstram, mesmo que ainda de modo inicial, uma participação mais livre das mulheres nos carnavais, notabilizados pelo seu caráter escarnecedor e por propiciar comportamentos e desejos ainda estigmatizados na esfera cotidiana.

\section{Referências}

ABREU, Regina. A capital contaminada: a construção da identidade nacional pela negação do "espírito carioca". In: LOPES, Antonio Herculano (Org.). Entre Europa e África: a invenção do carioca. Rio de Janeiro: Fundação Casa de Rui Barbosa, Topbooks, 2000. p. 167-185.

ACCIOLY NETTO, Antônio. O império de papel - Os bastidores de O Cruzeiro. Porto Alegre: Sulina, 1998.

ATRIZES mantêm tradição pouca roupa e muito tapa. Manchete, Rio de Janeiro, n. 305, p. 09, 22 fev. 1958.

AUGRAS, Monique. O Brasil do samba-enredo. Rio de Janeiro: Editora Fundação Getúlio Vargas, 1998.

BAKHTIN, Mikhail. A cultura popular na Idade Média e no Renascimento. O contexto de François Rabelais. Trad. de Yara Frateschi Vieira. São Paulo: HUCITEC/UnB, 1987.

BARRETO, Luis Carlos. S. M. A porta-bandeira. O Cruzeiro, Rio de Janeiro, n. 19, p. 116-117, 24 fev. 1951.

BARTHES, Roland. A câmara clara: nota sobre a fotografia. Rio de Janeiro: Nova Fronteira, 1984.

BASSANEZI, Carla. Mulheres dos anos dourados. In: PRIORE, Mary Del (Org.). História das mulheres no Brasil. 6 ed. São Paulo: Contexto, 2002. p. 607-639.

BASSANEZI, Carla. Virando as páginas, revendo as mulheres: relações homem-mulher e revistas femininas, 1945-1964. 1992. 454 f. Dissertação (Mestrado em História) - Faculdade de Filosofia, Letras e Ciências Humanas, Universidade de São Paulo, São Paulo, 1992.

BIQUÍNI com dez anos de atraso. O Cruzeiro, Rio de Janeiro, n.23, p.80, 18 mar. 1961. 
BRAGA, Amanda. História da beleza negra no Brasil: discursos, corpos e práticas. São Carlos: EdUFSCar, 2015.

BRAGA, João. História da moda. São Paulo: Editora Anhembi Morumbi, 2004.

BURNS, Mila. A dona da voz e a voz da dona: a trajetória de Dona Ivone Lara. In: VELHO, Gilberto (Org.). Rio de Janeiro: cultura, política e conflito. Rio de Janeiro: Jorge Zahar Ed., 2007. p. 108-127.

CAVALCANTI, Maria Laura Viveiros de Castro. Carnaval carioca: dos bastidores ao desfile. Rio de Janeiro: FUNARTE, 1994.

CHARTIER, Roger. A História Cultural. Entre Práticas e Representações. Tradução de Maria Manuela Galhardo. Lisboa: Difel, 1988.

CHATAIGNIER, Gilda. História da Moda no Brasil. São Paulo: Estação das Letras e Cores, 2010.

DIAS, Rosangela de Oliveira. O mundo como chanchada. Cinema e imaginário das classes populares na década de 50. Rio de Janeiro: Relume-Dumará, 1993.

ENTRAM em vigor hoje ao meio-dia as instruções do Chefe de Polícia. O Globo, Rio de Janeiro, 02 mar.1957, p.02.

FANTASIA, sim; Biquíni, não! O Globo, Rio de Janeiro, 10 fev. 1961, p. 09.

FARIA, Guilherme José Motta. As escolas de samba do Rio de Janeiro nos anos 60 e as narrativas sobre a história do negro na avenida. Faces da História, Assis, v.3, n. 2, p. 75-97, jul.-dez., 2016.

FERREIRA, Jorge. Espetacular desfile das escolas de samba. O Cruzeiro, Rio de Janeiro, n. 21, p. 17, 07 fev. 1953a.

_ _ _ _ _. Império Serrano. O Cruzeiro, Rio de Janeiro, n. 22, p. 06, 14 fev. 1953b.

FERREIRA, Felipe. O livro de ouro do carnaval brasileiro. Rio de Janeiro: Ediouro, 2004.

GRACO, Eduardo. Apaches invadem o Rio. O Cruzeiro, Rio de Janeiro, n. 13, p. 82, 12 jan. 1952.

LEMOS, Carlos; DAMATA, Gasparino. Terreiro de escola é oficina do samba. Manchete, Rio de Janeiro, n. 304, p. 59, 15 fev. 1958. 
LOPES, Nei; SIMAS, Luiz Antônio. Dicionário da história social do samba. Rio de Janeiro: Civilização Brasileira, 2015.

MORAES, Mário de; AUDI, Jorge; PASSOS, Hélio; LUIZ, Walter. Portela campeã do samba. $O$ Cruzeiro, Rio de Janeiro, n. 24, p. 143, 24 mar. 1962.

MUNICIPAL: de arlequim a pierrô: festa que contou com quase $8 \mathrm{mil}$ pessoas. O Cruzeiro, Rio de Janeiro, n. 19, p. 9, 21 fev. 1959.

O CARNAVAL nasce no morro. Manchete, Rio de Janeiro, n. 198, p. 30, 28 jan. 1956.

O CONCURSO começou fora: na passarela. Manchete, Rio de Janeiro, s/n, p. 42, 28 fev. 1959.

OLIVEIRA, Carlos. Fala Tarado!. Manchete, Rio de Janeiro, n. 46, p. 38, 07 mar. 1953.

PEREGRINO, Nadja. O Cruzeiro: a revolução da fotorreportagem. Rio de Janeiro: Dazibao, 1991.

QUEIROZ, Maria Isaura Pereira de. Carnaval brasileiro. O vivido e o mito. São Paulo: Brasiliense, 1992.

REGO, Costa. O carnaval das fotografias. Correio da Manhã, Rio de Janeiro, 24 fev. 1953, p. 04.

ROCHA, Antonio. Os ministros preferiram a bailarina mas... o morcego foi a fantasia mais aclamada. Manchete, Rio de Janeiro, n. 45, p. 22, 28 fev. 1953.

SANT’ANNA, Denise Bernuzzi de. História da beleza no Brasil. São Paulo: Contexto, 2014.

SILVA, Silvana Louzada da. Fotojornalismo em revista: o fotojornalismo em O Cruzeiro e Manchete nos governos Juscelino Kubitschek e João Goulart. Dissertação (Mestrado em Comunicação) - Programa de Pós-Graduação em Comunicação, Universidade Federal Fluminense, Niterói, 2004a.

SILVA, Zélia Lopes da. Os carnavais de rua e dos clubes na cidade de São Paulo: metamorfoses de uma festa (1923-1938). São Paulo: Editora Unesp; Londrina: Eduel, 2008.

SILVA, Zélia Lopes da. Os carnavais na cidade de São Paulo nos anos de 1935 a 1945. In: FENELON, Dea Ribeiro et al. (Orgs.). Muitas Memórias, Outras Histórias. São Paulo: Olho da Água, 2004b, p. 68-93. 
SIMSON, Olga R. de Moraes von. Mulher e carnaval: mito e realidade (Análise da atuação feminina nos folguedos de Momo desde o Entrudo até as Escolas de Samba). Revista de História, São Paulo, n. 125-126, p. 07-32, ago./dez. 1991 a jan./jul. 1992.

SOUZA, Rivailda do Nascimento. Depoimento. Entrevistadores: Aroldo Bonifácio, José Carlos Rego e Manoel Dionísio. Rio de Janeiro: Museu da Imagem e do Som - MIS. Entrevista concedida ao projeto "A sorte é sua em conhecer" no auditório da LOTERJ para o MIS/RJ em 2000 (VI 00758.3).

VASCONCELOS, Ary. O samba dá o toque de reunir. O Cruzeiro, Rio de Janeiro, n. 17, p. 48, 07 fev. 1959.

VASCONCELOS, Ary; ROCHA, Orlandino; RUDGE, Antonio; SOLARI, Jean; VIOLA, Geraldo; ALFREDO, Luiz; PASSOS, Hélio; AUDI, Jorge. Alegria e Milhões no Copacabana. O Cruzeiro, Rio de Janeiro, n. 23, p.123-129, 17 mar. 1962.

VELLOSO, Mônica Pimenta. As tias baianas tomam conta do pedaço: espaço e identidade cultural no Rio de Janeiro. Estudos Históricos, Rio de Janeiro, v. 3, n. 6, p. 207-228, 1990. 